\title{
ШЛЯХИ ФОРМУВАННЯ НОВОЇ ГЕНЕРАЦІЇ МЕДИЧНИХ СЕСТЕР ЧЕРЕЗ НЕОБХІДНІСТЬ НАУКОВО-ДОСЛІДНИЦЬКИХ УМІНЬ
}

\author{
Г. О. Сирова, В. М. Петюніна, О. В. Савельєва
}

\author{
Харківський національний медичний університет
}

\begin{abstract}
У статті обгрунтовано необхідність формування науково-дослідницьких умінь майбутніх медичних сестер у процесі навчання у вищому медичному навчальному закладі. За сучасних умов значно зросли вимоги до майбутнього фахівця сестринської справи, спричинені запитом конкретних роботодавців. Як відомо, сучасний ринок праці розглядає медичних сестер як персонал, здатний проводити і організовувати науково-дослідницьку роботу в лікувально-профілактичному закладі, який володіє науково-дослідницькими вміннями. Саме тому автори актуалізують значущість науководослідницьких знань і умінь в практичній охороні здоров’я та наявність відповідних їм організаційнопедагогічних умов у процесі професійної підготовки медичних сестер. Ефективне формування науководослідницьких якостей сприяє новітньому становленню медичної сестри як самостійної професійної одиниці з високим професійним потенціалом.
\end{abstract}

\section{WAYS OF FORMING A NEW GENERATION OF NURSES THROUGH THE NEED FOR RESEARCH SKILLS}

\author{
H. O. Syrova, V. M. Petunina, O. V. Savelieva
}

Kharkiv National Medical University

\begin{abstract}
The article substantiates the need for the formation of research skills of future nurses in the process of higher education. In modern conditions, the requirements for the future nursing specialist, caused by the request of specific employers, have significantly increased. As you know, the modern labor market considers nurses as staff capable of conducting and organizing research work in a treatment and prevention facility that has research skills. That is why the authors actualize the importance of research knowledge and skills in practical health care and the availability of appropriate organizational and pedagogical conditions in the process of professional training of nurses. Effective formation of research qualities contributes to the latest development of the nurse as an independent professional unit with high professional potential.
\end{abstract}

Вступ. Якість сучасної охорони здоров'я та стан здоров'я населення насамперед залежать від професіоналізму медичних працівників, зокрема медичної сестри. Середній медичний персонал становить найчисленнішу категорію співробітників і розглядається як особливо значущий ресурс практичної охорони здоров'я. За сучасних умов значно зросли вимоги до майбутнього фахівця сестринської справи, спричинені запитом конкретних роботодавців. Як відомо, сучасний ринок праці розглядає медичних сестер як персонал, здатний проводити і організовувати науково-дослідницьку роботу в лікувально-профілактичному закладі, який володіє науково-дослідницькими вміннями. Медична сестра, відповідно

(ㄷ.Г.О.Сирова, В. М. Петюніна, О. В. Савельєва, 2021 до очікувань роботодавців, характеризується як особистість, що володіє ініціативою, самостійністю в прийнятті рішень. За останні роки у медичній практиці відзначається, що в зарубіжній моделі сестринської справи саме такий персонал працює в клініках, проводить наукові дослідження, які дозволяють систематизувати їх роботу, вибирати пріоритетні напрямки, планувати і виконувати дії, що поліпшують стан пацієнта [1, 2]. Однак, підкреслимо, що випускники системи середньої медичної професійної освіти не відповідають висунутим вимогам і не володіють науково-дослідницькими вміннями тією мірою, яка необхідна сучасній охороні здоров'я, роботодавцю, а головне, задоволенню потреб населення в профілактиці, лікуванні захворювань і 
реабілітації. Загальновідомо, що сучасна медична сестра здійснює догляд за пацієнтом, проводить відновне лікування, навчає правильного способу життя при хронічних захворюваннях і травмах, що спричиняють втрату працездатності, елементам соціально адаптованої поведінки в суспільстві, проводить санітарно-просвітню роботу з населенням. Від того, наскільки така робота виконується професійно, грамотно і науково обґрунтовано, залежить у цілому якість наданих послуг і здоров'я населення. Саме тому за останні роки у вищих медичних навчальних закладах для підвищення професійної підготовки фахових медичних сестер, які відповідають очікуванням роботодавців та характеризуються як особистість, яка володіє ініціативою, самостійністю в прийнятті рішень, введено таку спеціальність, як «Медсестринство».

Основна частина. На сьогодні медична сестра не тільки помічник лікаря, а самостійна професійна одиниця зі сформованим науково-практичним потенціалом [3, 4]. Цілком очевидно, що охорона здоров'я потребує саме таких фахівців, а формування науково-дослідницьких умінь майбутніх медичних сестер $є$ актуальною проблемою професійної освіти. Впровадження нових освітніх стандартів, як відповіді на цю актуальну потребу, зумовило необхідність розробки і реалізації інноваційної стратегії в підготовці медичних кадрів середньої ланки. Формуванню дослідницьких умінь студентів у Харківському національному медичному університеті (ХНМУ) відводиться пріоритетна роль. Воно розглядається як одна з ключових компетенцій майбутньої медичної сестри. Ми вважаємо, що формування зазначених умінь має здійснюватися в процесі вивчення спеціальних дисциплін, але і кафедри теоретичного профілю, на яких навчаються першокурсники, закладають основи творчої діяльності майбутніх медичних сестер. Відповідно, завдання даного процесу полягають у тому, щоб навчити майбутніх медичних сестер у процесі професійної підготовки у вищому медичному навчальному закладі основам наукового дослідження, формуванню мотивів науково-дослідницької діяльності. Вирішення таких важливих завдань дає змогу не тільки підвищити якість підготовки, а й перетворює доктрину освітнього процесу в практико-орієнтований контекст. Звернемося до наукового трактування основних понять, включених в аналізований нами феномен: «вміння», «наукові знання», «дослідницькі вміння», «науково- дослідницькі вміння». Визначаючи сутність поняття «вміння», різні автори трактують їі по-різному. Так, С. Я. Батишев «вміння» визначає як здатність працівника, яка утворюється на основі знань і набутих навичок, продуктивно, з належною якістю і у відповідний час виконувати певну роботу. 3 точки зору В. А. Сластеніна, вміння - уміла дія, яка спрямована на чітке усвідомлення мети своєї діяльності. Воно утворюється в результаті вправ, які варіюють умови навчальної діяльності та передбачають ії поступове ускладнення. А. В. Усова, в свою чергу, розглядає «вміння» як здатність до цілеспрямованої та результативної діяльності. Аналіз наведених трактувань дозволив нам зробити висновок про те, що вміння - це дія, спрямована на результат, основу якого складають наукові знання і практична діяльність. Наукові знання, в свою чергу, включають факти, поняття, закони, закономірності, теорії, узагальнену картину світу [5]. Відповідно до освітньої функції вони повинні стати надбанням майбутнього професіонала, увійти в структуру його досвіду. Реалізація цієї функції забезпечує повноту, систематичність і усвідомленість знань, їх міцність і дієвість. Звернення до характеристики дослідницьких умінь як педагогічного поняття привело до висновку про те, що сфера його використання в науково-педагогічній літературі дуже обмежена: відсутнє точне визначення і характеристика компонентів. Відзначимо, що вивчення наукової літератури дозволило нам уточнити сутність поняття «вміння» як дії, що здійснюється в діяльності, а поняття «дослідження» як вивчення, з'ясування яких-небудь фактів, процесів або явищ на основі наявних знань. Відповідно, дослідницькі вміння - це здатність студента ефективно виконувати дії на основі використання знань, адекватних змісту кожного рівня системи освіти, вирішувати проблеми, які виникли перед нами, на основі наявних знань і умінь [6].

Таким чином, готовність до здійснення науководослідницької діяльності на основі використання знань і практичних умінь з усвідомленням мети, умов і засобів діяльності $\epsilon$ професійно значущою для особистості майбутньої медичної сестри. Науководослідницькі вміння в силу їх різноаспектної практико-орієнтованої специфіки представляють досить складну структуру і включають кілька компонентів. Ефективність науково-дослідницької діяльності студентів-бакалаврів зі спеціальності «Медсестринство» залежить від таких компонентів: мотиваційного, 
орієнтованого підходів; проблемних лекцій, практичних занять з елементами дослідження, методичних вимог і рекомендацій щодо організації різних форм науково-дослідницької діяльності [2]. Ми вважаємо, що, згідно з дослідницькими пріоритетами, доцільно виділити 3 компоненти: мотиваційний, що проявляється у вигляді пізнавального інтересу; змістовний, представлений спеціальними, які стосуються специфіки організації та проведення наукового й навчального дослідження, і предметними знаннями, що забезпечують базу вивчення і з'ясування певних процесів, фактів, явищ; операційний, що включає систему спеціальних, інтелектуальних і предметних умінь. Загалом науково-дослідницькі вміння - це прогнозовані способи дії, що забезпечують достовірність і об'єктивність дослідження, основаного на наукових знаннях, відповідно до його логіки. Одним з основних засобів формування науководослідницьких умінь майбутніх медичних сестер $\epsilon$ науково-дослідницька діяльність, яка розглядається як цілеспрямована організована індивідуальна або групова робота, спрямована на вирішення професійних завдань та реалізована у співпраці з викладачем в аудиторній і позааудиторній роботі. її результативність залежить від системності та послідовності, науково-педагогічного забезпечення, володіння викладачем науково-дослідницькими вміннями, готовності викладача займатися науково-дослідницькою діяльністю зі студентами, тим самим підвищуючи мотивацію студентів у даній галузі знань. Таким чином, ключові завдання умов формування науково-дослідницьких умінь майбутніх спеціалістів сестринської справи переважно полягають у тому, щоб: сформувати ціннісні орієнтири наукової діяльності; сформувати особливим чином організоване освітнє середовище, що сприяє розвитку навичок самостійної та творчої роботи студентів; розвинути навички спільної наукової діяльності в рамках творчої групи, яка має єдині цілі та завдання; сформувати вміння ведення наукової роботи, що тягне за собою становлення фахівця дослідника в стінах університету; створити інтелектуальні продукти на основі спільної роботи викладачів і студентів університету, що становлять основу для подальшого глибокого i систематичного вивчення профільних дисциплін. Таким чином, роль викладача в організації та проведенні науково-дослідницької діяльності в про- цесі навчання полягає в створенні необхідних умов для інтеграції науки і освіти в рамках професійної освіти, реалізації наукового потенціалу особистості студента медичного університету, підготовці конкурентоспроможного випускника зі сформованими науково-дослідницькими вміннями. Проблема формування науково-дослідницьких умінь майбутніх медичних сестер досить актуальна за умов сучасної професійної освіти. Оскільки це в подальшому підвищить авторитет і статус медичної сестри, допоможе змінити роль та раціональне використання середніх медичних працівників у системі охорони здоров'я. Такий підхід позитивно відобразиться на якості медичного обслуговування і максимальному охопленні населення медичною допомогою, буде сприяти скороченню витрат на охорону здоров'я, зниженню дефіциту лікарських кадрів [8].

Висновки. Від розвитку таких компетентностей медичних сестер, як вміння проявити ініціативу, своєчасно виявити перші симптоми і ознаки патологічних змін залежить рання діагностика і профілактика захворювань. Такі завдання охорони здоров'я, як формування культури здоров'я, пропаганда здорового способу життя, вирішення медико-соціальних проблем, ряд лікарських процедур і повноважень, можливість самостійного прийняття рішень повинні бути передані до компетенції медичної сестри. Реформи, що проводять в медицині, розширення зони професійної діяльності медичних сестер, підвищення їх професійного та соціального статусу починаються з удосконалення структури та змісту освітніх стандартів, з підготовки медичних працівників прикладного бакалаврату, інтегрованих із вищою медичною освітою і орієнтованих на міжнародний рівень. У зв'язку з цим, у ХНМУ розроблено нові навчальні програми, які містять практичні навички для студентів зі спеціальності «Медсестринство».

На практичних заняттях із дисципліни «Медична та біоорганічна хімія» $\epsilon$ завдання з елементами дослідження, а також студенти можуть брати участь у науковому гуртку «Кофеїн», що в цілому приводить до формування навчально-дослідницьких умінь. Ефективне формування науково-дослідницьких якостей сприяє новітньому становленню медичної сестри як самостійної професійної одиниці з високим професійним потенціалом. 


\section{СПИСОК ЛІТЕРАТУРИ}

1. Качний В. І. Формування у студентів дослідницьких навичок / В. І. Качний // Вища освіта сьогодні. - 2008. № 5. - С. 79-80.

2. Мазалецька А. Л. Мотивація науково-дослідницької діяльності студентів вузу / А. Л. Мазалецька // Вісник Університету (Державний університет управління). Соціологія і управління персоналом. - 2011. - № 6. - С. 61-62.

3. Новіков О. М. Форми навчання в сучасних умовах / О. М. Новіков // Фахівець. - 2006. - № 8. - С. 27-28.

4. Новосьолова О. Ю. Науково-дослідницька діяльність студентів як фактор підвищення конкурентоспроможності майбутніх фахівців / О. Ю. Новосьолова // Вісник вищої школи. - 2012. - № 11. - С. 35-37.
5. Перфільєва Г. М. Наукові дослідження в сестринській справі / Г. М. Перфільєва // Медична сестра. - 2006. № 4. - C. 40-41.

6. Сестринські дослідження за кордоном // Медична сестра. - 2008. - № 4. - С. 41-42.

7. Туркіна Н. В. Про організацію сестринських досліджень на сучасному етапі / Н. В. Туркіна // Медична сестра. - 2010. - № 1. - С. 42-43.

8. Цаплина О. В. Формирование профессиональных умений / О. В. Цаплина // Специалист. - 2006. - № 2. c. 33-34.

Отримано 08.09.21 